\title{
MICROPLASTICS IN LANDFILL LEACHATES IN THREE NORDIC COUNTRIES
}

\author{
Martijn van Praagh ${ }^{1,2, *}$ and Bettina Liebmann ${ }^{3}$ \\ ${ }^{1}$ Afry, Environment, Hallenborgs gata 4, 21174 Malmö, Sweden \\ ${ }^{2}$ Centre for Environmental and Climate Science, Lund University, Sölvegatan 37, 22362 Lund, Sweden \\ ${ }^{3}$ (formerly) Umweltbundesamt (Environment Agency Austria), Spittelauer Lände 5, 1090 Vienna, Austria
}

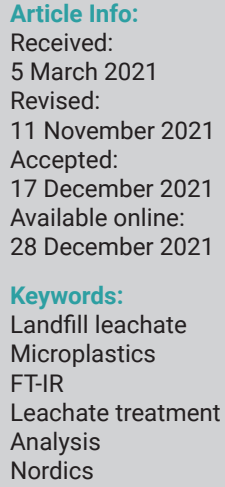

\begin{abstract}
We investigated the occurrence of microplastics (size range 5,000-50 $\mu \mathrm{m}$ ) in leachates at 11 landfills of different age and operational status in Finland, Iceland and Norway. Collective sampling was carried out by pumping leachate with a stainless-steel submergible pump through a custom-made, stainless-steel filter unit containing filter plates with decreasing pore sizes $(5,000,417$ and $47 \mu \mathrm{m}$, respectively). Samples were pre-treated and split into particles size classes above $500 \mu \mathrm{m}$ and above $50 \mu \mathrm{m}$, and screened for occurrence of microplastics made of PE, PP, PVC, PS, PET, PA, PU, PC, PMMA, POM, SBR (rubber) or PMB (polymer modified bitumen). Samples were analysed by FT-IR spectroscopy, both to identify and to count microplastic particles (SBR and PMB were merely identified). Most samples tested positive for multiple microplastics. Three leachates, including drinking water (blank), tested positive for SBR particles and/or PMB only. Treated leachate samples exhibited lower total microplastic's counts than untreated, up to several orders of magnitude. National waste management practices over time, landfill age or operational status do not seem to explain differences in microplastic abundance or counts between leachates. Particle count and calculated loads of microplastic emissions through leachates differed several orders of magnitude between landfills. Results indicate that landfill leachates might be a relatively small source of microplastics $(>50 \mu \mathrm{m})$ to surface waters compared to untreated and treated sewage or road runoff. Continued data acquisition, improved sample preparation and understanding of variability of microplastics in landfill leachate are necessary, including particles smaller than $50 \mu \mathrm{m}$.
\end{abstract}

\section{INTRODUCTION}

Although discovered in the oceans more than 40 years ago (Carpenter et al., 1972), microplastics have recently attracted growing public and scientific attention. Global plastics production is increasing, and expected to increase exponentially (Crawford and Quinn, 2017). Both macroplastics $(>5 \mathrm{~mm})$ and microplastics $(1 \mu \mathrm{m}<\mathrm{x}<5 \mathrm{~mm})$ are of great concern, as they can spread and be ingested by organisms. Microplastics have, amongst other, been detected in deep sea organisms (Pereira et al., 2020), in remote mountainous areas (Ambrosini et al., 2019), fish (Sequeira et al., 2020), bottled water for human consumption (Welle and Franz, 2018), and human stool (Schwabl et al., 2019). Plastics are considered a ubiquitous pollutant in the oceans (Eriksen et al., 2014). Some studies have shown that microplastics can have negative effects on aquatic and terrestrial organisms (Teuten et al., 2009; Deng et al., 2017). Microplastics have been suggested to act as vectors for antibiotic resistance genes (Su et al, 2021). Few studies, however, have indicated potential effects on freshwater ecosystems at microplastic concentrations currently observed in the environment (Triebskorn et al., 2019). The potential risks of adverse effects of particles as small as $1 \mu \mathrm{m}$, and of nanoparticles, on organisms are not well understood, though (Triebskorn et al., 2019, Sana et al., 2020). Waste management, especially landfilling of waste, has been pinpointed as a potentially significant source of microplastics (Sundt et al., 2014, Magnusson et al., 2016, Lestari and Trihadiningrum, 2019, Prata et al., 2020), in particular through the emission of landfill leachates, the liquid effluents from landfilled waste to surface waters. Leaching of various contaminants from landfills, including plastic additives, is well known and documented (Kjeldsen et al., 2002; Haglund et al., 2015; van Praagh et al., 2011 and 2013). However, comprehensive information on microplastic content in landfill leachates and on the potential impact of landfill leachate treatment on microplastic has only recently come into research focus (Kokalj et al., 2019; He et al., 2019).
Detritus / Volume 17 - 2021 / pages 58-70

https://doi.org/10.31025/2611-4135/2021.15149

(C) 2021 Cisa Publisher. Open access article under CC BY-NC-ND license 
In order to address the questions of landfill leachates as potential sources of microplastics and of efficacy of prevailing leachate treatment processes at landfills, the two working groups "Nordic Waste Group" and "Marine Group" under the Nordic Council of Ministers commissioned the design and completion of a study on the occurrence of microplastics in landfill leachates. (The Nordic Council is the official body for formal inter-parliamentary co-operation, formed in 1952 with members from Denmark, Finland, Iceland, Norway, Sweden, the Faroe Islands, Greenland and Åland). This study aimed at acquiring quantitative data on counts of microplastics, and at estimating their concentrations in leachates from landfills in Finland, Iceland and Norway (van Praagh et al., 2018). Furthermore, the aim was to acquire information on the impact of different leachate treatment methods on microplastic emissions, and to put potential microplastic emissions by landfill leachate into context with other potential sources of microplastics to surface water.

\section{METHODS AND MATERIAL}

\subsection{Sampling locations}

Leachate sampling took place during May 2018 (Iceland, then Finland, then Norway). After the sampling campaign in Finland, a stormwater pond receiving runoff from local highways in Stockholm, Sweden, was sampled. Loaded filter plates were removed from the filtering unit with a stainless-steel knife, placed in stainless steel boxes, sealed, packed, and delivered by courier to the laboratory at the Environment Agency Austria (Umweltbundesamt), Vienna, immediately at the end of each sampling campaign.

\subsubsection{Landfills}

Table 1 shows the type of landfill, location and information on operational status and leachate treatment at those landfills covered by this study. Landfills have been selected in order to reflect different levels of leachate treatment and operational status, type and estimated age of the landfilled wastes. Additionally, different landfilled classes (hazardous and non-hazardous) were to be included. In total, samples were taken at 11 different landfill sites in three different countries. At some locations, leachate could not be sampled separately from other potential microplastic sources such as storm water, service road runoff or recycling activities, as is common at waste management facilities in the Nordic countries. The ratio of landfill leachate in the effluents sampled varied, and was estimated to be between 70 and $100 \%$.

\subsubsection{Storm water pond}

A storm water pond in the municipality of Huddinge south of Stockholm, Sweden's capital, was selected for a reference sample. The pond has a surface area of approximately $670 \mathrm{~m}^{2}$ and a maximum depth of ca. $2.5 \mathrm{~m}$. The pond receives runoff from adjacent local roads, a $880 \mathrm{~m}$ stretch of a 2-by-2 lane regional inner state highway, as well as from non-paved areas. Approximately 7.5 ha drainage area are connected to the pond. In the Stockholm area, the nominal annual precipitation is $600 \mathrm{~mm}$.

\subsection{Definition of microplastics}

For this study, microplastic particles were defined as particles within the size range of $5 \mathrm{~mm}$ and $50 \mu \mathrm{m}$, consisting of manufactured polymers derived from petroleum or petroleum by-products. Landfill leachates were targeted for the following polymers:

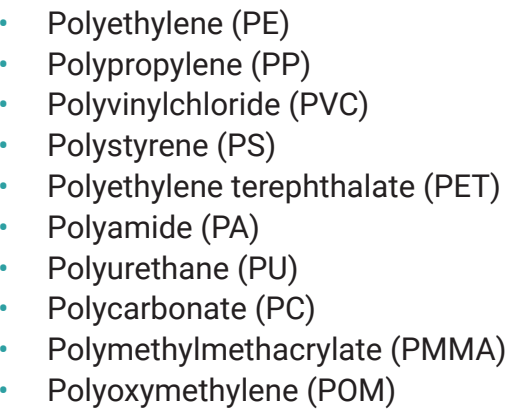

- Polypropylene (PP)

- Polyvinylchloride (PVC)

- Polystyrene (PS)

- Polyethylene terephthalate (PET)

- Polyamide (PA)

- Polyurethane (PU)

- Polycarbonate (PC)

- Polyoxymethylene (POM)

TABLE 1: Type and location of landfills covered in this study (type of waste disposed of: MSW = municipal solid waste, IW = industrial waste; landfill class: Non-haz = non-hazardous waste, Haz = hazardous waste; landfills with years of operation, "-date" still in use at the time of sampling; effluents at sampling point: $\mathrm{L}=$ landfill leachate, $\mathrm{RR}=$ road runoff; $\mathrm{S}=$ storm water, $\mathrm{W}=$ other waste processing; minor contribution in brackets).

\begin{tabular}{|c|c|c|c|c|c|c|}
\hline Country & No. & Landfill class & Type of waste & Leachate treatment type & $\begin{array}{l}\text { Main effluents to } \\
\text { sampling point }\end{array}$ & Years of operation \\
\hline \multirow[t]{5}{*}{ Finland } & 1 & Non-haz & MSW & None & $\mathrm{L}$ & 1971-1989 \\
\hline & 2 & Non-haz & MSW, IW & None & $\mathrm{L}(\mathrm{S})$ & 1989-date \\
\hline & 3 & $\mathrm{Haz}$ & IW & Filtration and active carbon & $\mathrm{L}$ & 1989-date \\
\hline & 4 & Non-haz & MSW, IW & Artificial soil filtration & $L,(S)$ & $1980-2001$ \\
\hline & 5 & Non-haz & MSW & None & $L, W$ & $1959-2007$ \\
\hline \multirow[t]{3}{*}{ Norway } & 6 & Non-haz & MSW, IW & Sequencing batch reactor & $L$ & 1989-date \\
\hline & 7 & Non-haz & Mixed & None & $L$ & 2009-date \\
\hline & 8 & Non-haz & MSW, IW & None & $L,(R R, S)$ & NN-1987 \\
\hline \multirow[t]{3}{*}{ Iceland } & 9 & Non-haz & MSW, IW & Sand bed filtration & $\mathrm{L},(\mathrm{S} ?)$ & 2012-date \\
\hline & 10 & Non-haz & MSW, IW & None & $\mathrm{L}$ & 2004-2012 \\
\hline & 11 & Non-haz & MSW, IW & None & L, (S?) & 1989-date \\
\hline
\end{tabular}


- Styrene-Butadiene-Rubber (SBR, essentially the main component in tyre rubber)

- Polymer-Modified Bitumen (PMB, an admixture in asphalt paving, e.g., see Zhu et al., 2014)

According to PlasticsEurope, 2018, the first 10 polymers in the list above represent the major share of plastics produced globally.

\subsection{Sampling and analysis}

\subsubsection{Collective sampling}

Sampling was carried out by means of pumping leachate through three custom-made stainless-steel filter plates with decreasing mesh sizes, incorporated in a stainless-steel unit. Filter mesh width were 5000, 411, and 47 $\mu \mathrm{m}$, respectively (filter unit designed and provided by Resource International, Iceland). A submersible, stainless steel pump (Proril X-SMART, 400A, 2", 0.4kW/230V/50 $\mathrm{Hz}$ ) was connected via a reinforced PVC-hose attached to brass hose nipples on the stainless-steel filter housing. The filter unit was equipped with a flow meter and a pressure release valve. Flow meter readings were annotated prior and after each sampling occasion. At two sampling campaigns, in Finland and Iceland, flow meter readings were cross-refenced by means of timing filling containers with known volumes.

In some cases, leachate was collected in a bucket (PE) and subsequently pumped through the filter unit as described above (see Annex 1). Reasons for this approach were either extremely low water levels after a dry spring, or lack of accessibility at the sampling location.

In order to evaluate potential cross-contamination of leachate samples due to a) occupational safety gear of the staff; b) the PVC hose and power cable connected to the pump; and c) the use of plastic buckets, a blank sample with drinking water was collected at landfill 3 and included in the study as a control, or "blank". The presence of plastic materials used during sampling was documented (photographed and labels identified). Sampling locations and sampling volumes collected are described in Annex 1. Pumping and filtration took place until pressure built-up stalled further sampling, and flow was negligible or came to a total standstill. This was checked visually by observing that flow meter needles remained idle. The pressure release valve did not open during sampling on any occasion, which means that pressure was always below 1 bar.

An exception from this rule occurred when sampling storm water. The sample was collected by means of hauling a stainless-steel bucket attached to a stainless-steel wire repeatedly but at different lengths into the water pond (maximum 10 meters from the shore). The individual grab samples were then administered to the filtration apparatus directly, without using the stainless-steel pump. Sampling continued until no flow or dripping could be observed from the filter unit anymore.

\subsubsection{Sample pre-treatment}

Filter plates and containers were back-flushed with ultrapure water (Milli-Q, particle filter $0.22 \mu \mathrm{m}$ ) and treated with hydrogen peroxide $\left(15 \% \mathrm{H}_{2} \mathrm{O}_{2}\right)$ for at least five days to remove non-plastic organic matter (see for example Claessen et al., 2013; Cole et al., 2014; Nuelle et al., 2014; Imhof et al., 2012). Some samples were additionally treated with small amounts of hydrochloric acid $(10 \% \mathrm{HCl}$, see for example Eriksen et al., 2013). The solid matter remaining after the chemical pre-treatment was wet-sieved through 500 and $50 \mu \mathrm{m}$ metal sieves, and thus separated into two size fractions: (1) particles larger than $500 \mu \mathrm{m}$ and (2) particles of size 50-500 $\mu \mathrm{m}$ (Hohenblum et al., 2015; Robertson et al., 2015). Either size fraction ( $>500 \mu \mathrm{m}$ and $50-500 \mu \mathrm{m})$ was removed from the metal sieves into ultrapure water. This particle-water suspension was homogenized, and a representative aliquot was transferred onto an inorganic filter membrane (Whatman Anodisc, $47 \mathrm{~mm}$ diameter, 0.2 $\mu \mathrm{m}$ pore size) via vacuum filtration, and subsequently dried at maximum $60^{\circ} \mathrm{C}$, as residual humidity can interfere the IR-signal. The total mass of solid residue was calculated by the weight differences before and after chemical treatment.

Intermittently, all lab equipment was rinsed several times with ultrapure water that was pre-filtered through a $50 \mu \mathrm{m}$ stainless steel sieve. In addition, a blank sample, undergoing the whole sample preparation procedure was analysed: No micro plastic was found in the blank sample.

\subsubsection{Analysis}

Sample preparation for the qualitative and quantitative analysis included representative subsampling and loading of particles onto an inorganic filter membrane (aluminium oxide), which were then analysed by $\mu$-FT-IR (Fourier transform infrared)-spectroscopy and imaging (Spotlight 400, PerkinElmer Inc., USA). Subsampling was performed by suspending the samples' particles in water in a beaker. Numerous subsamples were subtracted while stirring the suspension. These subsamples were then combined and analyzed. Each subsample represented at least $20 \%$ of the respective total sample. In screening mode, samples were checked for occurrence of PE, PP, PVC, PS, PET, PA, PU, PC, PMMA, and POM (result of screening: present yes/no).

For each sample, a total area of $12.5 \mathrm{~cm}^{2}$ was then scanned via imaging for acquisition of transmission infrared spectra. Via software assisted comparison (based on correlation, SpectrumIMAGE, Version R1.8.2 0413, PerkinElmer Inc., USA) with reference materials from a spectra database, the "chemical image" of the filter (2D map plus IR spectra) was evaluated for the polymers (see above), with an exemption for rubber (SBR) and polymer modified bitumen (PMB). Microplastic particle occurrence was estimated with the help of the counts of unambiguously identified particles.

Samples of three different SBR from two different Swedish producers as well as three different types of car tyres (PMB) were scanned and added to the laboratory's IR reference material database. Samples of SBR were collected by removing ca. $3 \times 3 \mathrm{~cm}^{2}$ large parts from disposed tyres at a workshop. For screening of SBR and PMB particles, a different measurement technique was applied; rather than scanning from a distance in the so-called transmission mode, the ATR (attenuated total reflection)-FT-IR micro-spectroscopy established contact between a Germanium crystal and the suspected particles for reflection 
measurements. The crystal was positioned onto 5 different spots on the filter, each of which exhibited an area of 0.16 $\mathrm{mm}^{2}$, where SBR/PMB particles were preliminary identified visually. The total sample area that was screened for the presence of SBR/PMB particles resulted in $0.8 \mathrm{~mm}^{2}$. As this is only a tiny fraction of the total sample area, SBR and $\mathrm{PMB}$ particles were neither counted nor their numbers estimated. The ATR-measurements were combined with imaging.

\subsection{Mass calculations}

Microplastic counts per litre were used to calculate mass concentration with the following assumptions.

- Uniform density of particles of the same polymer

- Density $\left(\mathrm{kg} / \mathrm{l}\right.$ or $\left.\mathrm{Mg} / \mathrm{m}^{3}\right)$ PA: $1.05, \mathrm{PE}: 0.965, \mathrm{PET}: 1.45$, PMMA: 1.20, PP: 0.91, PS: 1.1, PU: 1.2, PVC: 1.58 (maximum values in GESAMP, 2015, or Hidalgo-Ruz et al., 2012)

- Uniform shape (globe)

- Radius $r=50 \mu \mathrm{m}$ (exception storm water sample $>500$ $\mu \mathrm{m}: r=250 \mu \mathrm{m})$

No mass calculations for SBR and PMB have been undertaken, as these were only identified as part of the screening.

\section{RESULTS AND DISCUSSION}

\subsection{Screening results}

Results from screening to elucidate the occurrence of microplastic particles in samples after pre-treatment and re-filtering are shown in Annex 2 alongside the mass loading on the filters. No microplastics were found on $5000 \mu \mathrm{m}$ filter meshes. Microplastics initial count and total amount of particulate matter remaining in the sample after chemical pre-treatment are depicted.

The mass of the remaining particles after chemical treatment can be used as an indicator of total microplastics' amounts in samples. The chemical treatment prior to the analysis described above does, however, not completely remove non-target matter. The $50 \mu \mathrm{m}$ sample from landfill 8 reacted heavily upon contact with pre-treatment chemicals, producing precipitation residues. Large amounts of remaining insoluble inorganic residues impaired the screening for microplastics. An additional investigation into the nature of reaction products revealed prevailing minerals containing iron and silica. Double-checking with the landfill operator did not reveal any chemical anomalies in the sample which might suggest what caused the reaction with pre-treatment agents. The leachate from the sample point is normally rich in iron, but this is not uncommon for MSW-landfill leachates.

Generally, negligible numbers of microplastic particles of the size 5000-500 $\mu \mathrm{m}$ were detected, with an exception for the storm water sample. Rather, particles much smaller than $500 \mu \mathrm{m}$, and approximately closer to $50 \mu \mathrm{m}$ were detected on the $411 \mu \mathrm{m}$ screens. Consequently, a partition in particle size fractions was not considered meaningful, and results are displayed as sum of particles $>50 \mu \mathrm{m}$ subsequently. Microplastics (including SBR and PMB) where detected in all samples. In three samples, a single polymer was detected: SBR residue was found in treated leachate from landfill no 6 , leachate from no 10 , as well as in the blank sample.

Abundance of identified plastics in leachate samples is shown in Figure 1. Except for PE, it differs from polymer production figures for EES/EU27. Historical data indicates that few changes in ranking of abundance have occurred since production started (Roland et al., 2017).

The lack of larger particles might be explained by the fact that landfill leachate quality is likely to be dominated by the lowest waste layer deposited, or rather the lowest layer of waste contributing to leachate drainage. The porosity of this layer i likely to be relatively low due to degradation of organic material and compression (Bleiker et al., 1995; Muaaz-Us-Salam et al., 2019). It can be assumed that small pore size restricts larger particles being drained.

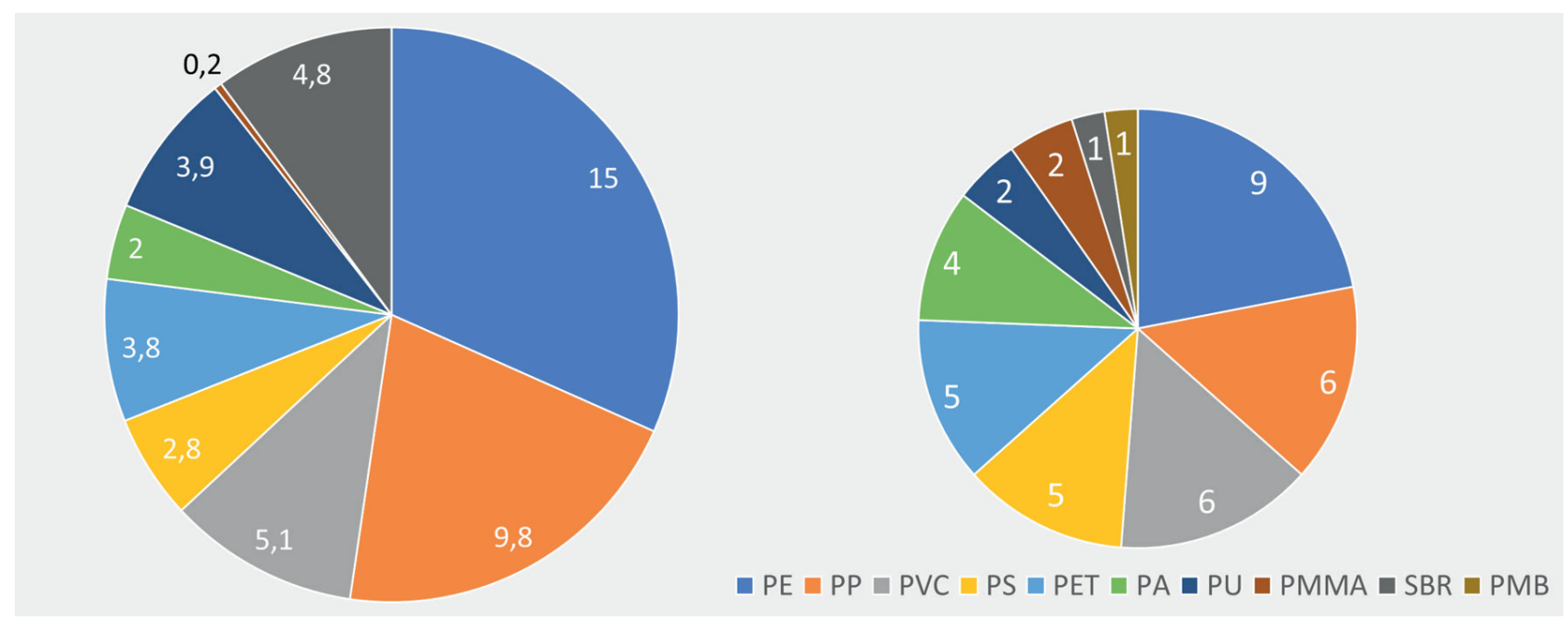

FIGURE 1: Production of polymers in Mtons (left, polymers for extrusion in EES-countries, year 2017, PlasticsEurope, 2018; SBR = tire production EU27, Echa, 2017), and abundance of polymers identified in leachate sample screening (right, total counts for all samples, PC = n.d.). 
The presence of SBR in the blank sample indicates that cross-contamination has occurred. At first, residues from the rubber seals between sections of the filter unit were suspected.

However, the rubber seal material is significantly different from SBR-samples used for IR-imaging control spectra, and mixing up spectra is highly unlikely. The tap water for the blank sample was collected through a 5-meter-long reinforced PVC hose and pumped from the same bucket (PE) used at locations were submerging the stainless-steel pump was not possible. Staff was wearing personal protection equipment (PPE) comprising of PVC-gloves and PET-clothing. Consequently, contamination with these polymers might be expected, but was not detected. As the PE-bucket was open to the atmosphere at landfill site No. 3 , where the blank sample was taken, air-born particles might have entered the sample. Although the sampling equipment was rinsed, filter plates renewed after each sampling occasion and the filter unit swapped with paper towels between sampling occasions, cross-contamination from prior sampling occasion cannot be ruled out. At this point, sources of sample contamination can neither be unambiguously identified nor ruled out.

\subsection{Results from microplastic quantification}

In Table 2, the microplastic counts and concentration as counts per sampling volume are displayed (observe that PMB and SBR were only screened for but could not be quantified, see the discussing section).

As can be derived from the results displayed in Table 2, polymer particles were quantified in all samples, except for the control sample (No. 0), and leachate samples Nos. 5, 6-treated and 10. The restrictions of the analytical method for black particles (see chapter 2), let to SBR- and PMB-particles not being accounted for, although they were identified in the previous "screening".

The number of different identified polymers varies from 0 to 7 between samples, with PE being the most abundant polymer, found in 11 of 15 leachate samples with a total of 301 counts. Overall, counts in treated samples are ca 1 or even 2 orders of magnitude lower than in untreated samples, except for landfill no 3.

PE was found to be the dominant polymer in other studies on both leachate and other sources, as well (see Table 3, and even Silva et al., 2021, for a compilation of microplastic counts in landfill leachates).

Although differences between landfills/waste treatment facilities appear in the first three studies depicted in Table 3, the order of magnitude of observed maximum microplastics' counts per liter in leachates appears to be comparable. Su et al., 2021, and Xu et al., 2020, reported concentrations almost three orders of magnitude higher.

\subsection{National differences and years of landfill opera- tion}

Little is known about the main factors influencing microplastic particle release from landfills (Silva et al., 2021). Still, the amount and kind of plastic waste entering the landfill is likely to play a role, together with other potential sources of microplastics, such as recycling operations and service road runoff on site, atmospheric deposition, as well as materials used in leachate or landfill gas collection and treatment systems. Economic growth (Gardiner and Hajek, 2020), laws and regulations (van Praagh and

TABLE 2: Results from microplastic quantification (counts $>50 \mu \mathrm{m}$, blank cells $=$ non detect).

\begin{tabular}{|c|c|c|c|c|c|c|c|c|c|c|}
\hline No. & PE & PP & PVC & PS & PET & PA & PU & PMMA & Total count & Count/l \\
\hline 0 control & & & & & & & & & & 0 \\
\hline 1 & 13 & 6 & & & & & & & 19 & 0.16 \\
\hline 2 & 19 & & 15 & 17 & 25 & 4 & 8 & 4 & 88 & 1.10 \\
\hline 3 untreated & & & & & 9 & & 9 & & 18 & 0.30 \\
\hline 3 treated & 25 & & & 35 & & & & & 60 & 0.32 \\
\hline 4 untreated & 41 & & & 16 & 8 & & 73 & & 138 & 1.97 \\
\hline 4 treated & 4 & & & 2 & & & & & 6 & 0.03 \\
\hline 5 & & & & & & & & & & 0 \\
\hline 6 untreated & 22 & & & & 4 & & & & 26 & 1.3 \\
\hline 6 treated & & & & & & & & & & 0 \\
\hline 7 & 6 & & & & 51 & & & 26 & 57 & 1.40 \\
\hline 8 & 10 & & & & & & & & 10 & 1.00 \\
\hline 9 untreated & 14 & & & 2 & 4 & & 40 & & 60 & 0.20 \\
\hline 9 treated & 15 & & & & & & & & 15 & 0.06 \\
\hline 10 & & & & & & & & & & 0 \\
\hline 11 & 132 & 25 & & 17 & & & 25 & & 199 & 4.51 \\
\hline Storm water $50 \mu \mathrm{m}^{a}$ & 8 & 23 & & 10 & 109 & & & & 150 & 4.17 \\
\hline Storm water $500 \mu \mathrm{m}$ a & 8 & 6 & & 16 & 51 & & & & 81 & 2.25 \\
\hline
\end{tabular}

a particles of PVC, PMMA, PA and PU were not quantified (fewer than 5 particles detected in screening-mode) 
TABLE 3: Compilation of results from studies on microplastics in leachates.

\begin{tabular}{|c|c|c|c|c|c|c|c|}
\hline Study & $\begin{array}{c}\text { No } \\
\text { samples }\end{array}$ & $\begin{array}{l}\text { Size range } \\
{[\mu \mathrm{m}]}\end{array}$ & $\begin{array}{l}\text { Analytical } \\
\text { technique }\end{array}$ & Count/I & $\begin{array}{l}\text { No of polymers included/ } \\
\text { identified (most abundant) }\end{array}$ & Comment & Reference \\
\hline This study & 15 & $50-5,000$ & FT-IR & $0-4.5$ & 11/11 (PE) & & Van Praagh et al., 2018 \\
\hline $\begin{array}{l}\text { Treated leachates } \\
\text { in Sweden }\end{array}$ & 7 & $\geq 100$ & $\begin{array}{l}\text { Mi- } \\
\text { cro-scope }\end{array}$ & $0-2.7$ & - & $\begin{array}{l}\text { Waste facilities with } \\
\text { landfill }\end{array}$ & $\begin{array}{c}\text { Swedish Waste Associ- } \\
\text { ation, } 2018\end{array}$ \\
\hline $\begin{array}{l}\text { Sorting facility } \\
\text { Sweden }\end{array}$ & 1 & $\geq 100$ & $\begin{array}{l}\text { Mi- } \\
\text { cro-scope }\end{array}$ & $2.3-4.2$ & - & $\begin{array}{l}\text { Waste facility with- } \\
\text { out landfill }\end{array}$ & $\begin{array}{l}\text { Swedish Waste associ- } \\
\text { ation, } 2018\end{array}$ \\
\hline Chinese landfills & 12 & $25-500$ & FT-IR & $0.4-2.6$ & 17/17 (PE) & & He et al., 2019 \\
\hline Chinese landfill & 18 & $10-150$ & $\mu$-Raman & $\varnothing 235$ & 12/27 (PE) & a & Su et al., 2021 \\
\hline Chinese landfills & $1^{\mathrm{b}}$ & $20-100$ & FT-IR & 291 & 4/? (PP) & & Xu et al., 2020 \\
\hline
\end{tabular}

${ }^{a}$ raw leachate, study covered different parts of leachate collection and treatment system; ${ }^{b}$ duplicate

Persson, 2006), consumption habits (Kagawa et al., 2007), cultural aspects in economic sectors (Ajayi et al., 2016), type of waste management strategy and organisation (Lestari and Trihadiningrum, 2019); all these factors impact on amounts and types of waste going to landfill. Landfilling of (micro)plastics and microplastic emissions through leachates might be dependent on those factors, as well.

Plastics have been and are still target of direct or indirect waste management policy efforts in the Nordic Countries (Norden, 2017; Papineschi et al., 2019). Differences in recycling performance occur (Behzad et al., 2020; Zaman and Swapan, 2016). Performance figures for MSW management in the Nordic countries and EU average are displayed in Figures 2, 3 and 4 (data from Norden, 2020, where available; the term "Nordic countries" is used to discuss the data and figures, although not all Nordic Countries are included in the data).

Figure 2 indicates that most Nordic countries have a per capita MSW production comparable to the EU-aver- age. Exceptions are Denmark with a continuously higher per capita production, and Norway. The apparent steep decrease in waste production year 2001, as well as the apparent steep increase in 2016 are suspected to reflect different input data or different definitions of "MSW", rather than real developments in MSW per capita.

Over time, percentages of collected MSW going to landfills have differed considerably between the Nordic countries (Figure 3). Although following the EU-average until year 2001, a much larger proportion of MSW ended up in landfills in Norway compared to Sweden, Denmark and Greenland. The same is true for Finland until 2016, and it appears to be true for Iceland year 2018. Residual waste, i.e. non-source separated waste is likely to contain plastic waste (Papineschi et al., 2019).

Only three active landfills covered in this study started operation in the time frame covered in the data behind Figures 2 to 4: two in Iceland (triangles in Figure 2) and one in Finland (dot in Figure 3).

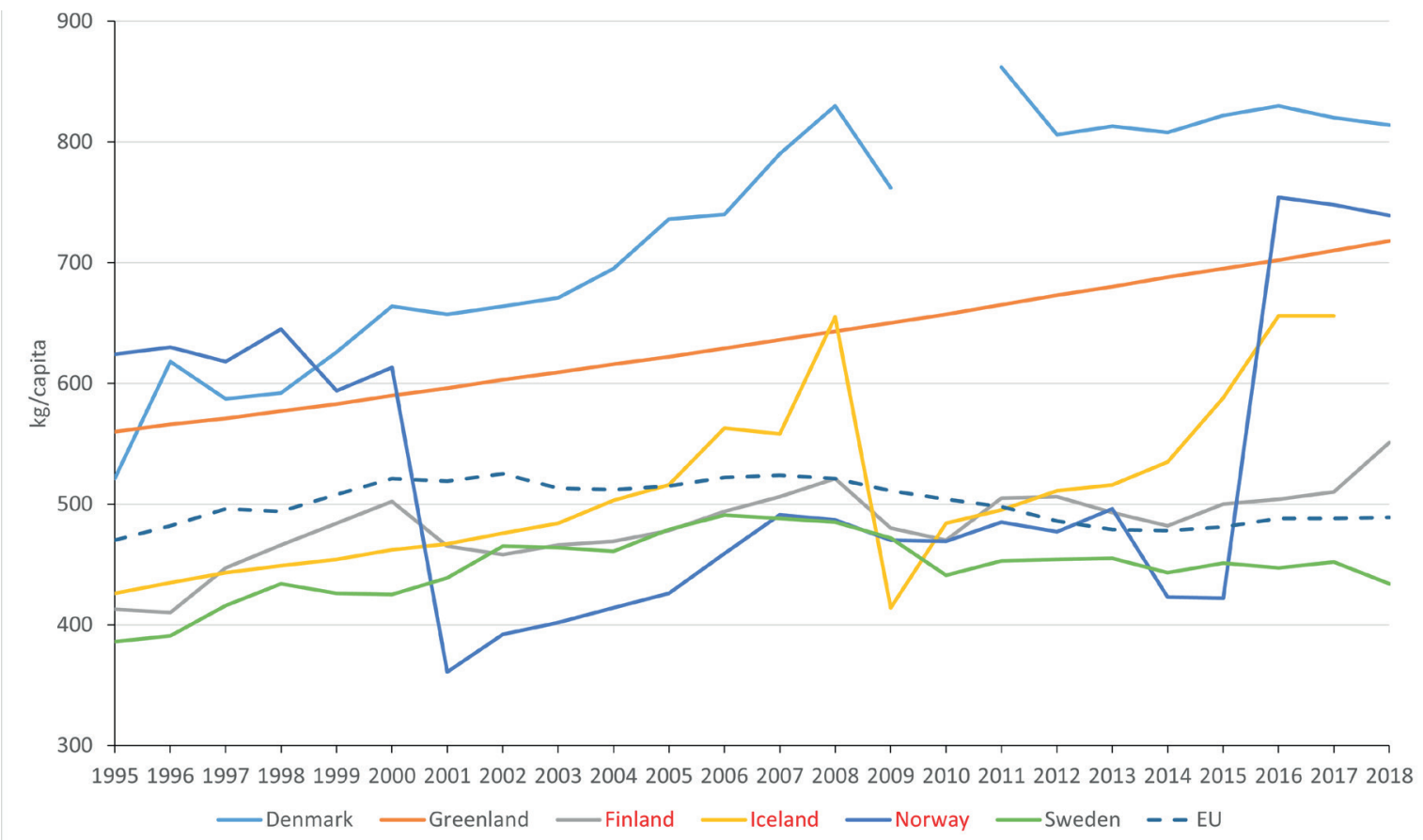

FIGURE 2: Municipal solid waste produced per capita in some Nordic countries (in $\mathrm{Kg} / \mathrm{capita}$; countries covered in this study in red text, EU depicts average of member countries, cut lines = missing data; different number of countries apply through timeline; Norden, 2020. Different definitions of "household waste" might apply, see e.g., Papineschi et al., 2019). 


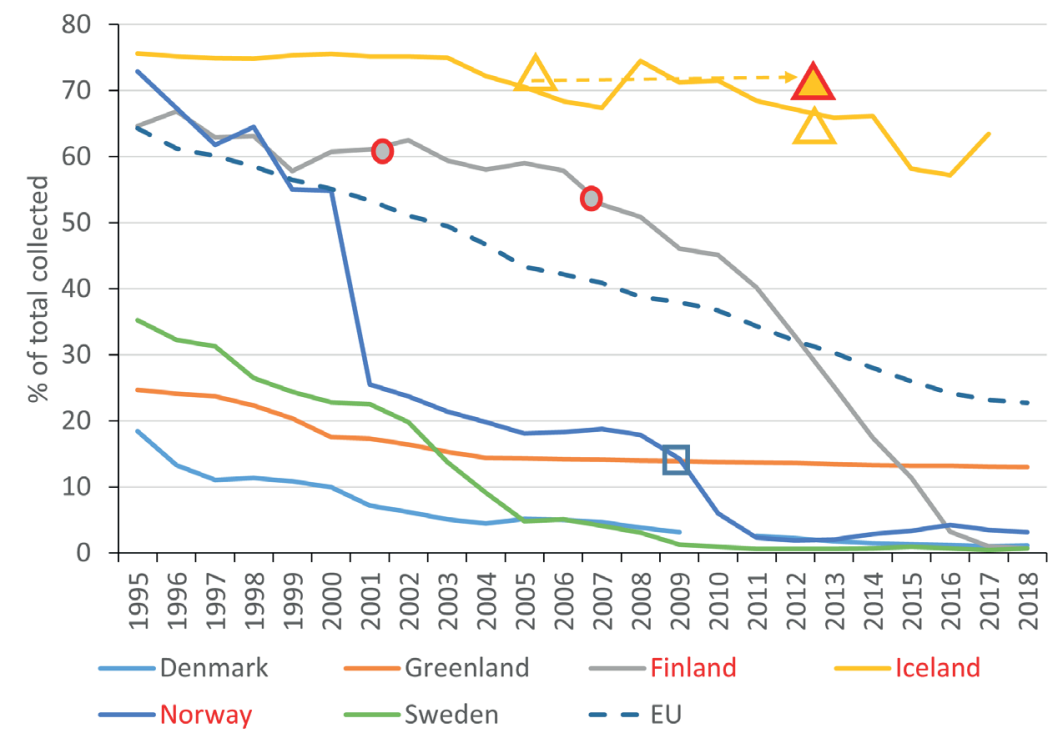

FIGURE 3: Municipal solid waste landfilled (deposited onto or into land) in Nordic countries (in \%; countries covered in this study in red text, EU depicts average of member countries, cut lines = missing data, symbols depict year of start (blank symbols) or closure (solid symbols with red outline) for Iceland (triangel), Norway (box) and Finland (dot) in the indicated time period; Norden, 2020).

Generally, resource efficiency regarding plastics have increased in Nordic countries over time (see Figure 4, and, e.g., Robaina et al., 2020). As can be derived from Figure 4, material recycling rates in Finland and Norway were considerably higher than the EU-average up until around $2007 / 2008$. Recently, recycling rates have moved closer to the EU-average, which in turn has steadily increased since 1995. The data behind Figure 4 covers a wide range of materials such as metal, paper, cardboard and plastic, and plastic material recovery lags (Robaina et al., 2020; Milios et al., 2018). Consequently, it can be assumed that between 95 and $70 \%$ of plastics in MSW have not been subject to material recycling in the Nordic countries between 1995 and 2018; either they ended up in waste incineration, were exported, became litter, or - to a smaller extent - were disposed of at landfills prior to landfill bans on combustible waste (observe that this observation is true for plastic packaging only for items not subject to deposit-refund-schemes). Diversion of plastics from landfills started not least in the wake of the EU landfill directive and related waste acceptance criteria (EC, 1999 and EC, 2002).

Although Norway and Iceland remain outside the union, Norway's landfill regulations are similar to the EU's, such prohibiting landfilling of organic waste, and separate collection of plastic packaging waste is available in more than $80 \%$ of municipalities (Papineschi et al., 2019). Still, even without a detailed look at particular waste acceptance data from the landfills included in this study, it is safe to assume that plastic materials have been disposed of at the landfills,

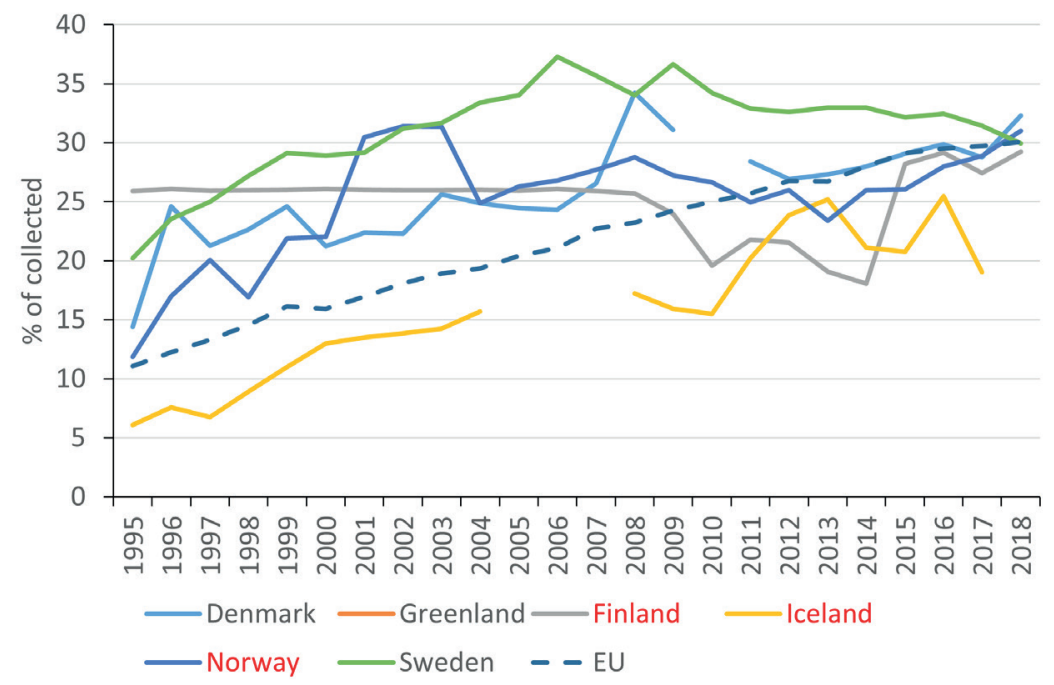

FIGURE 4: Municipal solid waste recycled (material recycling) in some Nordic countries (in \%, countries covered in this study in red text, EU depicts average of member countries, cut lines = missing data; Norden, 2020). 
albeit in different amounts and with declining rates since turn of the last century.

(Micro)plastics are relatively recalcitrant to degradation (Barnes et al., 2009). Plastics are found in abundance in waste from landfill excavation (Canopoli et al., 2018). Still, biodegradation has been shown to occur, even under anaerobic conditions, and by microbes isolated from landfills (Ganesh Kumar et al., 2020; Giacomucci et al., 2020, Park and Kim, 2019). Aging, alteration and degradation might occur over time in the waste body (Hou et al., 2021; Su et al., 2021). However, landfill conditions are unlikely to be favourable for microbial degradation of plastics, not least due to the abundance of other, more readily available microbial substrates and mass-transfer limitations (Shah et al., 2009; Canopoli et al., 2020; Tansel, 2019, Ishigaki et al., 2004). Still, differences in microplastic emissions might be expected between landfills of different age due to the factors stated above.

Figure 5 depicts the number of microplastic counts per litre leachate in untreated leachates against the number of years since start of landfill operation, with the additional information of country of origin and mode of operation for each landfill.

Leachate samples from landfills in Iceland exhibit both non-detect and the highest microplastic counts per litre. Microplastic counts in leachate samples from Norway show relatively little variation (average count per litre for all untreated leachate samples is $0.995^{-1}$ ). As the active Finnish landfills started operating round about the same time (1987 to 1989, blue dots in Figure 5), similar age, operational procedures and/or similarities in waste disposed of might lead to comparable microplastic concentrations in counts per litre. With the data at hand, this cannot, however, be verified statistically.

Considering the limited data on microplastic counts in leachate samples, and the lack of detailed information about amounts and types of plastic waste actually landfilled at the sampling locations, no link can be drawn between the two.

\subsection{Landfill leachates as sources of microplastics}

In Table 4, the summarized analytical results of microplastics in landfill leachate are put into perspective to results from other published studies, both on different microplastics sources and pathways. Scope, sampling methods and analytical techniques differ widely between studies. Particle size cut-offs differ considerably between studies. Therefore, results have not been recalculated to mass-concentrations. Consequently, the loads emitted by different sources should be regarded preliminary indications.

\subsection{Limitations and potential sources of error}

Not least due to the lack of standardization regarding sampling and analysis of microplastics, certain sources of error cannot be ruled out. No duplicate or triplicate samples have been analysed, and the sampling method has not been verified with spiked samples with known microplastic contamination. As a result, error margins and detection limits are not verifiable, which warrants caution when interpreting results. Optical analytical methods such as FT-IR are susceptible to influence from non-plastic material in samples, and pre-treatment to remove non-target material has been shown to impact analytical results (Masura et al., 2015, Simon et al., 2018, Collard et al., 2015). Thus, an initial follow-up trial on a number of samples taken in this study has been conducted at Lund University. Samples on aluminium oxide filter plates from the initial FT-IR analysis have been re-examined.

Initial results indicate that increasing the $\mathrm{H}_{2} \mathrm{O}_{2}$ concentration from 15 to $30 \%$ (reaction time 6 days) enables previously unidentified plastic particles to become "visible" in

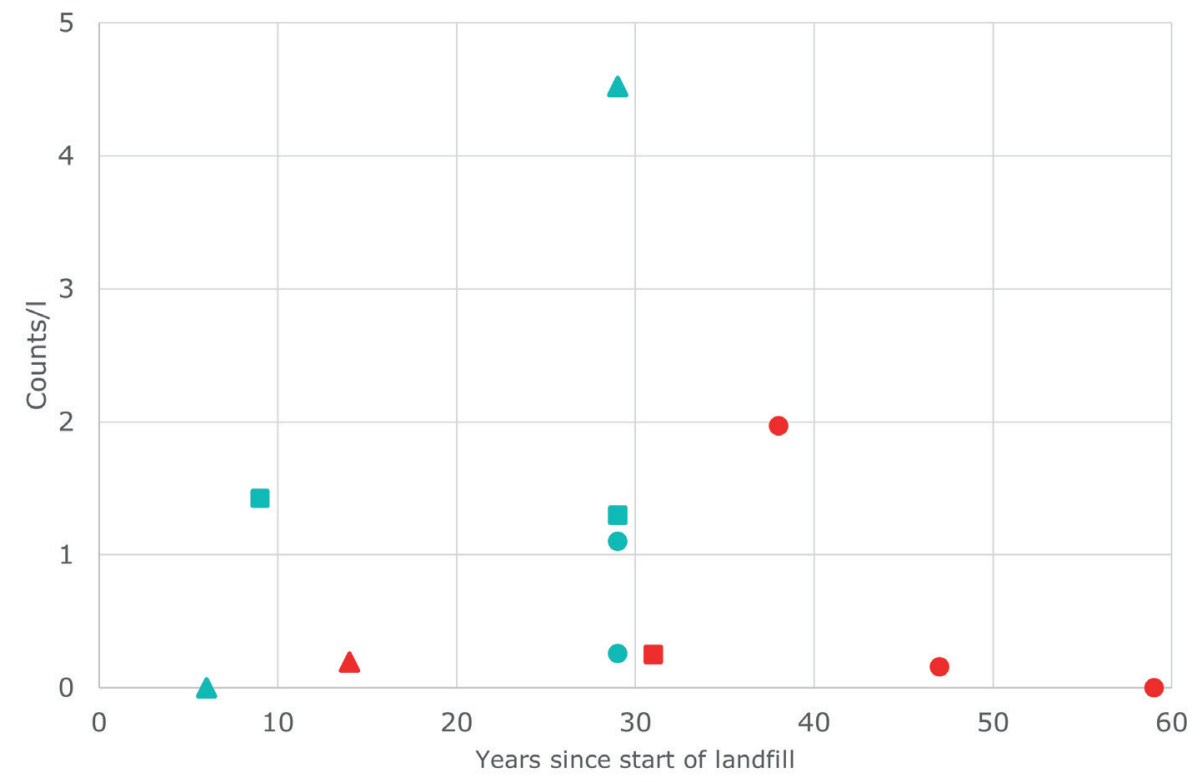

FIGURE 5: Years since start of landfill operation vs. microplastic count per litre in untreated leachates with country indicated (triangle=Iceland, box=Norway, dot=Finland; closed landfills are represented in red). 
TABLE 4: Approximated microplastic concentrations and estimated loads from different potential sources/pathways.

\begin{tabular}{|c|c|c|c|c|c|}
\hline $\begin{array}{l}\text { Source/ } \\
\text { pathway }\end{array}$ & $\begin{array}{l}\text { Particle size range } \\
\qquad \mu \mathrm{m}\end{array}$ & $\begin{array}{l}\text { Count/L } \\
(\mu \mathrm{g} / \mathrm{L})\end{array}$ & Annual Load & Comment & Reference \\
\hline Landfills & $50-5,000$ & $\begin{array}{l}0-4.5^{\mathrm{a}} \\
(0-2.4)\end{array}$ & $15 \mathrm{~g}-25 \mathrm{~kg}^{\mathrm{b}}$ & on average & $\begin{array}{c}\text { This study; van Praagh } \\
\text { et al. } 2018\end{array}$ \\
\hline Landfills in Sweden & $\geq 100$ & $0-2.7$ & $0-170 \mathrm{~kg}$ & treated leachate & $\begin{array}{c}\text { Swedish Waste } \\
\text { Association, } 2017\end{array}$ \\
\hline $\begin{array}{l}\text { Incoming Sewage to } \\
\text { WWTP, Sweden }\end{array}$ & $>20$ & $20-80$ & $2.6 \cdot 10^{12}$ particles & & $\begin{array}{l}\text { Magnusson and } \\
\text { Wahlberg, } 2014\end{array}$ \\
\hline $\begin{array}{l}\text { Effluent WWTP, } \\
\text { Sweden }\end{array}$ & $>20$ & $10-100$ & $2.6 \cdot 10^{11}$ particles & & $\begin{array}{l}\text { Magnusson and } \\
\text { Wahlberg, } 2014\end{array}$ \\
\hline Traffic in Sweden & $>100$ & n.d. & 7,670 tons & & Magnusson et al., 2016 \\
\hline $\begin{array}{l}\text { Storm water pond } \\
\text { inner-city highway }\end{array}$ & $5000-50$ & $\begin{array}{c}6.4 \\
(195)\end{array}$ & c & & This study \\
\hline Air deposition in Paris & $100-5,000$ & & 3-10 tons fibres & & Dris et al., 2016 \\
\hline $\begin{array}{l}\text { Artificial turfs in } \\
\text { Sweden }\end{array}$ & $>100$ & n.d. & $1,640-2,460$ tons & & Magnusson et al., 2016 \\
\hline $\begin{array}{l}\text { Players on artificial } \\
\text { turfs in Norway }\end{array}$ & & $2 \mathrm{ml}$ & 65 tons & $\begin{array}{c}2 \mathrm{ml} \text { per game and } \\
\text { player }\end{array}$ & Sintef, 2018 \\
\hline
\end{tabular}

${ }^{a}$ calculated with the assumption in chapter $2.5 ;{ }^{b}$ calculated with annual leachate production volume for the last year available, provided by the respective landfill operator (see van Praagh et al., 2018 for details); ${ }^{c}$ as the sample was not taken in the outflow but from the water body of a pond, emissions cannot be calculated

the filter residues (Simongini, 2021), putting into question whether microplastic counts might actually be higher than depicted above.

As a result of the sampling method, variations in particle content of the leachates caused different sampling volumes, as sampling prevailed until the smallest filter got clogged. Sampling a fixed amount of leachate at one occasion with subsequent filtration in the laboratory would most likely have given different results. In that case, the chance of "catching" microplastics would have been much lower. If microplastic particle concentrations were, in fact, correlated to particle concentrations of non-plastic matter in leachates, the sampling method chosen for this study should have enabled representative sampling.

Sampling pre-treatment might have removed or altered microplastic particles (Karami et al. 2017).

Although similarities of different SBR-materials and different polymer-modified bitumen are likely to create similar and coherent FT-IR patterns, it cannot be ruled out that microplastic particles of significantly different blends of both materials than those used as references might go undetected in leachate samples: According to a producer of polymer modified bitumen, there is an almost unlimited number of blends that can be used with different fractions of added polymers.

The polymers included in the screening represent the main plastics used in the Technosphere (>80\%). Still, it cannot be ruled out that microplastics of non-targeted polymers were present in the samples.

The filter equipment was cleaned between samples, and treated samples were taken before untreated samples. Still, cross-contamination cannot be ruled out, which is indicated by SBR particles in the blank sample.

The choice of lower size limit of $50 \mu \mathrm{m}$ (47 $\mu \mathrm{m}$ during sampling) is likely to exclude numerous smaller particles. Particularly regarding microplastic particles from PE and PVC, but also others, it cannot be ruled out that these at least partly stem from landfill drainage and leachate treatment and collection systems rather than from the landfilled waste itself. This could, for example, explain the occurrence of PE and PS particles in the treated leachate at landfill 3 (although an investigation into the material used in the on-site treatment facility was inconclusive).

The variation of (micro)particles in landfill leachates over time, and factors influencing the emission of these have, to the knowledge of the authors, not been subject of comprehensive studies before. Silva et al. (2021) pointed out this knowledge gap, as well. Consequently, variations of microplastic concentration in leachate, e.g., seasonal variations or the influence of heavy rainfall events, are not accounted for in this study (what is more, the northern hemisphere experienced unusual weather conditions year 2018, with large, but relatively early, spring floods, and extremely dry and warm weather during the sampling campaign). Although landfill leachate treatment methods appeared to be effective for the sum of microplastic particles (5000-50 $\mu \mathrm{m}$ ) with reduction ratios of between 3 and 100\%, the sources of error mentioned above restrict comprehensive conclusions regarding treatment efficacy.

Although the landfills covered in this study, with the exception of the hazardous waste landfill no. 3 in Finland, were chosen as "typical landfills" in their respective countries, it is unknown how representative they actually are when it comes to the emission of microplastic particles in the Nordic countries as a whole.

\section{CONCLUSIONS}

Microplastic counts and the abundance of different microplastic polymers vary largely in leachates sampled at landfills in Finland, Norway and Iceland. Counts and calculated annual loads from leachate emissions appear to be small compared to other sources or pathways such as untreated and treated sewage and road runoff. Based 
on the results from this study, the underlying hypothesis of landfills generally being a relatively large source of microplastics is put in doubt. As this study neither covered time-series nor duplicate samples, and weather conditions were extraordinary at most locations, further studies are needed to determine the range of microplastics concentrations in treated and untreated leachates.

In 3 out of 4 studied cases, landfill leachate treatment seems to significantly reduce the counts of microplastics larger than $50 \mu \mathrm{m}$. Future work on microplastics should focus on standardization of leachate sampling and finetuning analytical techniques, in order to comprehensively elucidate the variability of microplastic concentrations in landfill leachates and of treatment efficacy, despite the challenging chemical matrix landfill leachates often present. Quantification methods for tyre rubber and polymer-modified bitumen microplastics should be developed, and future sampling and analysis of landfill leachates should include microplastic particles smaller than $50 \mu \mathrm{m}$, preferably even nanoparticles.

\section{AKNOWLEDGEMENTS}

This study was financed by the Nordic Council of Ministers. Help from the initiators and steering group comprising of Guðmundur B. Ingvarsson, Yvonne Augustsson, Hanna Salmenperä and Jon Fonnlid Larsen amongst others (all members of the Nordic Waste Group) in close co-operation with the Marine Group, is gratefully acknowledged, as is the help of Cornelia Hartman, Emma Brandmyr and Ola Wik (Afry). Help with providing the sampling equipment, as well as the sampling in Iceland by Jamie McQuilkin, Lea Böhme and Nicolas Marino Proietti (Resource International) is gratefully acknowledged, as is the analytical work by Sebastian Köppel, Gerrit Hermann, Felizitas Zeitz, Martina Göß and Helmut Weber (Umweltbundesamt). Last but not least, the invaluable help of the staff at the participating landfills and Fredrik Erlandsson at Stockholm municipal Water and Waste utility is duly recognized and appreciated.

\section{REFERENCES}

Ambrosini, R., Azzoni, R.S., Pittino, F., Diolaiuti, G., Franzetti, A., Parolini, M., 2019. First evidence of microplastic contamination in the supraglacial debris of an alpine glacier, Environmental Pollution, vol. 253, pp. 297-301

Ajayi, S.O., Oyedele, L.O., Akinade, O.O., Bilal, M., Owolabi, H.E., Alaka, H.A., Kadiri, K.O., 2016. Reducing waste to landfill: A need for cultural change in the UK construction industry. Journal of Building Engineering, Volume 5, 2016, Pages 185-193, ISSN 2352-7102. https://doi.org/10.1016/j.jobe.2015.12.007.

Behzad, M., Zolfani, S.H., Pamucar, D., Behzad, M., 2020. A comparative assessment of solid waste management performance in the Nordic countries based on BWM-EDAS, Journal of Cleaner Production, Volume 266, 2020, 122008, ISSN 0959-6526, https://doi. org/10.1016/j.jclepro.2020.122008.

Barnes, D.K., Galgani, F., Thompson, R.C., Barlaz, M., 2009. Accumulation and fragmenta tion of plastic debris in global environments. Philos. Trans. R. Soc. B 364, 1985-1998.

Bleiker, D.E., Farquhar., G., McBean, E., 1995. Landfill settlement and the impact on site capacity and refuse hydraulic conductivity. Waste Management \& Research 13: 533-554.

Canopoli, L., Fidalgo, B., Coulon, F., Wagland, S.T., 2018. Physico-chemical properties of excavated plastic from landfill mining and current recycling routes, Waste Management, Volume 76, 2018, Pages 55-67, ISSN 0956-053X, https://doi.org/10.1016/j.wasman.2018.03.043.
Canopoli, L., Coulon, F., Wagland, S.T., 2020. Degradation of excavated polyethylene and polypropylene waste from landfill, Science of The Total Environment, Volume 698, 2020, 134125, ISSN 0048-9697, https://doi.org/10.1016/j.scitotenv.2019.134125.

Carpenter, E.J., Anderson, S.J., Harvey, G.R., Miklas, H.P., Peck, B.B., 1972. Polystyrene spherules in coastal waters. Science, 178 (4062), pp. 749-750.

Cole, M., Webb, H., Lindeque, P.K., Fileman, E.S., Halsband, C., Galloway, T.S., 2014. Isolation of microplastics in biota-rich seawater samples and marine organisms. Scientific Reports 4: 4528, DOI: $10.1038 /$ srep04528.

Collard, F.; Parmentier, E.; Das, K.; Gilbert, B.; Eppe, G., 2015. Detection of anthropogenic particles in fish stomachs: an isolation method adapted to identification by Raman spectroscopy. Arch. Environ. Contam. Toxicol., 69 (3) (2015), pp. 331-339

Crawford, C.B, and Quinn, B. 2017. 3 - Plastic production, waste and legislation, in Microplastic Pollutants (Editor(s): Christopher Blair Crawford, Brian Quinn,Elsevier, 2017, Pages 39-56, ISBN 9780128094068 .

Deng Y, Zhang Y, Lemos B, Ren H. 2017. Tissue accumulation of microplastics in mice and biomarker responses suggest widespread health risks of exposure. Sci.Rep. 7:1-10.

Dris, R., Gasperi, J., Saad, M., Mirande, C., Tassin, B., 2016. Synthetic fibers in atmospheric fallout: A source of microplastics in the environment? Marine Pollution Bulletin. 2016;104(1-2):290-293. oi:10.1016/j.marpolbul.2016.01.006

EC, 1999. Council Directive 99/31/EC of 26 April 1999 on the landfill of waste. Official Journal L 182, 16/07/1999, 0001 - 0019.

EC, 2002. Council Decision of 19 December 2002 establishing criteria and procedures for the acceptance of waste at landfills pursuant to Article 16 of and Annex II to Directive 1999/31/EC. Official Journal L 011, 16/01/2003, 0027 - 0049.

Echa, 2017. Annex XV Report: An Evaluation of the possible Health Risks of Recycled Rubber Granules uses as Infill in Synthetic Turf Sport Fields. https://echa.europa.eu/documents/10162/13563/ annex-xv_report_rubber_granules_en.pdf/dbcb4ee6-1c65-af357a18-f6ac1ac29fe4.

Eriksen, M., Mason, S., Wilson, S., box, C., Zellers, A., Edwards, W., Farley, H., Amato, S., 2013. Microplastic pollution in the surface waters of the Laurentian Great Lakes. Marine Pollution Bulletin 77: 177-182.

Eriksen, M., Lebreton, L.C.M., Carson, H.S., Thiel, M., Moore, C.J., 2014. Plastic Pollution in the World's Oceans: More than 5 Trillion Plastic Pieces Weighing over 250,000 Tons Afloat at Sea. PLoS ONE 9(12): e111913. doi:10.1371/journal.pone.0111913

Ganesh Kumar. A., Anjana K., Hinduja M., Sujitha K., Dharani G., 2020. Review on plastic wastes in marine environment - Biodegradation and biotechnological solutions, Marine Pollution Bulletin, Volume 150, 2020, 110733, ISSN 0025-326X, https://doi.org/10.1016/j. marpolbul.2019.110733.

Gardiner, R., Hajek, P., 2020. Municipal waste generation, R\&D intensity, and economic growth nexus - A case of EU regions, Waste Management, Volume 114, 2020, Pages 124-135, ISSN 0956-053X, https://doi.org/10.1016/j.wasman.2020.06.038.

GESAMP, 2015. Sources, fate and effects of microplastics in the marine environment: a global assessment. (Kershaw, P. J., Ed.) IMO/ FAO/Unesco-IOC/WMO/IAEA/UN/UNEP - Joint Group of Experts on the Scientific Aspects of Marine Environmental Protection (GESAMP)(90). ISSN 1020-4873.

Giacomucci, L., Raddadi, N., Soccio, M., Lotti, N., Fava, F. 2020. Biodegradation of polyvinyl chloride plastic films by enriched anaerobic marine consortia, Marine Environmental Research, Volume 158, 2020, 104949, ISSN 0141-1136, https://doi.org/10.1016/j.marenvres.2020.104949.

Haglund, P., Holmgren, T., Olofsson, U., Arnoldsson, K., Westerdahl, J., Tivander, J., Molander, S., van Praagh, M., Törneman, N., Humston-Fulmer, L., 2015. Goldschmidt Abstracts, 20151145

He, P., Chen, L., Shao, L., Zhang, H., Lü, F., 2019 Municipal solid waste (MSW) landfill: A source of microplastics? - Evidence of microplastics in landfill leachate, Water Research, Volume 159, 2019, Pages 38-45, ISSN 0043-1354, https://doi.org/10.1016/j. watres.2019.04.060.

Hidalgo-Ruz, V., Gutow, L., Thompson, R. C. \& Thiel, M., 2012. Microplastics in the Marine Environment: A Review of the Methods used for Identification and Quantification. Environmental Science \& Technology, 46(6), s. 3060-3075. 
Hohenblum, P., Frischenlager, H., Reisinger, H., Konecny, R., Uhl, M., Mühlegger, S., Habersack, H. Liedermann, , M., Gmeiner, P., Weidenhiller, B., Fischer, N., Rindler, R. 2015. Plastic in the Danube River (in German: Plastik in der Donau. Untersuchung zum Vorkommen von Kunststoffen in der Donau in Österreich). Reports, Bd. REP-0547. Umweltbundesamt, Vienna, Austria.

Hou, L. Kumar, D., Geun Yoo, C., Gitsov, I., Majumder, E.L.-W. 2021. Conversion and removal strategies for microplastics in wastewater treatment plants and landfills, Chemical Engineering Journal, Volume 406, 2021, 126715, ISSN 1385-8947, https://doi. org/10.1016/j.cej.2020.126715.

Imhof, H.K., Schmid, J., Niessner, R., Ivelva, N.P., Laforsch, C., 2012. A novel, highly efficient method for the separation and quantification of plastic particles in sediments of aquatic environments. Limnology and Oceanography: Methods 10: 524-537.

Ishigaki, T., Sugano, W., Nakanishi, A., Tateda, M., Ike, M., Fujita, M. 2004. The degradability of biodegradable lastics in aerobic and anaerobic waste landfill model reactors, Chemosphere, Volume 54, Issue 3, 2004, Pages 225-233, ISSN 0045-6535, https://doi. org/10.1016/S0045-6535(03)00750-1.

Kagawa, S., Nakamura, S., Inamura, H., Yamada, M., 2007. Measuring spatial repercussion effects of regional waste management, $\mathrm{Re}$ sources, Conservation and Recycling, Volume 51, Issue 1, 2007, 141-174, ISSN 0921-3449, https://doi.org/10.1016/j.resconrec.2006.09.001.

Karami, K., Golieskardi, A. , Choo, C.K., Romano, N., Ho, Y.B., Salamatinia,B. 2017. A high-performance protocol for extraction of microplastics in fish. Science of The Total Environment, Vol. 578, p. 485-494, https://doi.org/10.1016/j.scitotenv.2016.10.213

Kjeldsen, P., Barlaz, M.A., Rooker, A.P., Baun, A, Ledin, A., Christensen, T.H. (2002). Present and Long-Term Composition of MSW Landfill Leachate: A Review. Critical Reviews in Environmental Science and Technology, 32(4):297-336

Kokalj, A.J., Kuehnel, D., Puntar, B., Gotvajn, A.Z., Kalčikova, G., 2019. An exploratory ecotoxicity study of primary microplastics versus aged in natural waters and wastewaters, Environmental Pollution, Volume 254, Part A, 2019, 112980, ISSN 0269-7491, https://doi. org/10.1016/j.envpol.2019.112980.

Lestari, P., Trihadiningrum, Y., 2019. The impact of improper solid waste management to plastic pollution in Indonesian coast and marine environment, Marine Pollution Bulletin, Volume 149, 2019 110505, ISSN 0025-326X, https://doi.org/10.1016/j.marpolbul.2019.110505.

Magnusson, K., Eliasson, K., Fråne, A., Haikonen, K., Hultén, J., Olshammar, M., Stadmark, J. and Voisin, A., 2016. Swedish sources and pathways for microplastics to the marine environment. A review of existing data. IVL Swedish Environmental Research Institute (IVL Svenska Miljöinstitutet): 87.

Magnusson, K., Wahlberg, C., 2014. Microlitter in WWTP-effluentes (in Swedish Mikroskopiska skräppartiklar i vatten från avloppsreningsverk). IVL-report B2208

Masura, J., Baker, J., Foster, G., Arthur, C., 2015. Laboratory Methods for the Analysis of Microplastics in the Marine Environment: Recommendations for Quantifying Synthetic Particles in Watersand Sediments, Vol. 39

Milios, L., Holm Christensen, L., McKinnon, D., Christensen, C., Rasch, M.K., Hallstrøm Eriksen, M., 2018. Plastic recycling in the Nordics: A value chain market analysis, Waste Management, Volume 76 2018, Pages 180-189, ISSN 0956-053X, https://doi.org/10.1016/j. wasman.2018.03.034

Muaaz-Us-Salam, S., Cleall, P.J., Harbottle, M.J. 2019. The case for examining fluid flow in municipal solid waste at the pore-scale A review. Waste management \& research, 2019;37(4):315-332. doi:10.1177/0734242X19828120

Norden, 2017. Nordic programme to reduce the environmental impact of plastic. Nordic Council of Ministers, ISBN 978-92-893-50020 (EPUB)http://dx.doi.org/10.6027/10.6027/ANP2017-730ANP 2017:730

Norden, 2020. Data on waste management, (Norden, 2020). Eurostat and Statistics Greenland, data retrieved from Eurostat: 20200612, and Nordics statistics database, https://www.nordicstatistics.org/ environment-and-energy/, accessed 10/10/2020.

Nuelle, M.T., Dekiff, J.H., Remy, D., Fries, E., 2014: A new analytical approach for monitoring microplastics in marine sediments. Environmental Pollution 184: 161-169.
Papineschi, J., Hogg, D., Chowdhury, T., Durrant, C., Thomson, A., 2019. Analysis of Nordic regulatory framework and its effect on waste prevention and recycling in the region. TemaNord 2019:522, http:// dx.doi.org/10.6027/TN2019-522.

Park, S.Y., Kim, C.G., 2019. Biodegradation of micro-polyethylene particles by bacterial colonization of a mixed microbial consortium isolated from a landfill site, Chemosphere, Volume 222 2019, Pages 527-533, ISSN 0045- 535, https://doi.org/10.1016/j. chemosphere.2019.01.159.

Pereira, J.M., Rodríguez, Y., Blasco-Monleon, S., Porter, A., Lewis, C., Pham, C.K., 2020. Microplastic in the stomachs of open-ocean and deep-sea fishes of the North-East Atlantic. Environmental pollution (Barking, Essex : 1987). 2020;265(Pt A):115060. doi:10.1016/j.envpol.2020.115060

PlasticsEurope, 2018. Plastics - the Facts, 2018. An analysis of European plastics production, demand and waste data. Brussels, Belgium 2018

Prata, J.C., da Costa, J.P.. Lopes, I., Duarte, A.C., Rocha-Santos, T., 2020. Environmental status of (micro)plastics contamination in Portugal, Ecotoxicology and Environmental Safety, Volume 200, 2020, 110753, ISSN 0147-6513, https://doi.org/10.1016/j. ecoenv.2020.110753.

Robaina, M., Murillo, K., Rocha, E., Villar, J., 2020. Circular economy in plastic waste - Efficiency analysis of European countries, Science of The Total Environment, Volume 730, 2020, 139038, ISSN 00489697, https://doi.org/10.1016/j.scitotenv.2020.139038.

Robertson, I., Lohkamp-Schmitz, G., Liebmann, B., 2015: The application of infrared microscopy for the analysis of microplastics in water-borne environmental samples. Poster, Pittcon Konferenz, 8. -12.3.2015, New Orleans, US

Roland, G., Jambeck, J.R., Lavender Law, K., 2017. Production, use, and fate of all plastics ever made. Science Advances 19 Jul 2017:Vol. 3, no. 7, e1700782, DOI: 10.1126/sciadv. 1700782

Sana, S.S., Dogiparthi, L.K., Gangadhar, L. et al. Effects of microplastics and nanoplastics on marine environment and human health. Environ Sci Pollut Res (2020). https://doi.org/10.1007/s11356-02010573-x

Schwabl, P., Koppel, Konigshofer, S., Bucsics, T., Trauner, M., Reiberger, T., Liebmann, B., 2019. Detection of Various Microplastics in Human Stool - A Prospective Case Serie. Ann Intern Med. 2019;171:453-457. doi:10.7326/M19-0618.

Sequeira, I.F., Prata, J.C., da Costa, J.da P., Duarte, A.C., Rocha-Santos, T. 2020. Worldwide contamination of fish with microplastics: A brief global overview, Marine Pollution Bulletin, Volume 160, 2020, 111681 ,

ISSN 0025-326X, https://doi.org/10.1016/j.marpolbul.2020.111681.

Shah, A.A., Hasan, F., Hameed, A., Ahmed, S., 2008. Biological degradation of plastics: a comprehensive review. Biotechnol. Adv. 26, 246-265.

Silva, A.L.P., Prata, J.C., Duarte, A.C., Soares, A.M.V.M., Barceló, D., Rocha-Santos, T. 2021. Microplastics in landfill leachates: The need for reconnaissance studies and remediation technologies, Case Studies in Chemical and Environmental Engineering, Volume 3, 2021, 100072, ISSN 2666-0164, https://doi.org/10.1016/j.cscee.2020.100072

Sintef, 2018. Sjekk kunstgressbanen - Forskningskampanjen 2017. Via: https://www.sintef.no/siste-nytt/12-000-elever-har-kartlagtgummigranulat/; visited 14-3-2019.

Simon, M., van Alst, N., Vollertsen, J., 2018. Quantification of microplastic mass and removal rates at wastewater treatment plants applying Focal Plane Array (FPA)-based Fourier Transform Infrared (FT-IR) imaging. Water Research 142 (2018) 1-9.

Simongini, C., Pucetaite, M., Serranti S., Hammar, E., van Praagh, M., Bonifazi, G., 2021. Microplastic identification in landfill leachates by different spectroscopic techniques, Proceedings Sardinia Symposium 2021, Cagliari, Italy.

Su, Y., Zhang, Z., Zhu, J., Shi, J., Wei, H., Xie, B., Shi, H. 2021. Microplastics act as vectors for antibiotic resistance genes in landfill leachate: The enhanced roles of the long-term aging process, Environmental Pollution, Volume 270, 2021, 116278, ISSN 0269-7491, https://doi.org/10.1016/j.envpol.2020.116278.

Sundt, P., Schulze, P.-E., Syversen, F., 2014. Sources of microplastic pollution to the marine environment. Mepex for the Norwegian Environment Agency (Miljødirektoratet): 86. 
Swedish Waste Association, 2018. Microplastics in treated leachate a case study of eight waste treatment facilities (in Swedish). Report 2018:21, Avfall Sveriges Utvecklingssatsning, ISSN 1103-4092

Tansel, B., 2019. Persistence times of refractory materials in landfills: A review of rate limiting conditions by mass transfer and reaction kinetics, Journal of Environmental Management, Volume 247, 2019, Pages 88-103, ISSN 0301-4797, https://doi.org/10.1016/j. jenvman.2019.06.056

Teuten E .L., Saquing, J. M., Knappe, D. R. U., Barlaz, M. A., Jonsson, S., Björn, A., Rowland, S. J., Thompson, R. C., Galloway, T. S., Yamashita, R., Ochi, D., Watanuki, Y., Moore, C., Viet, P. H., Tana, T. S., Prudente, M., Boonyatumanond, R., Zakaria, M. P., Akkhavong, K., Ogata, Y., Hirai, H., Iwasa, S., Mizukawa, K., Hagino, Y., Imamura, A., Saha, M., Takada, H., 2009. Transport and release of chemicals from plastics to the environment and to wildlife. Phil. Trans. R. Soc. B 364, 2027-2045.

Triebskorn, R. Braunbeck, T., Grummt, T., Hanslik, L., Huppertsberg, S. Jekel, M., Knepper, T.P., Krais, S., Müller, Y.K., Pittroff, M. Ruhl, A.S., Schmieg, H. Schür, C., Strobel, C., Wagner, M., Zumbülte, N. Köhler, H.-R., 2019. Relevance of nano- and microplastics for freshwater ecosystems: A critical review, TrAC Trends in Analytical Chemistry, Volume 110, 2019, Pages 375-392, ISSN 0165-9936, https://doi. org/10.1016/j.trac.2018.11.023

van Praagh, M., Persson, K. M., 2006. National Translation of the EU landfill directives: Will Swedish Landfills become sustainable? Journal of Sustainable Development and Planning, 1, 46-60.

van Praagh, M., Törneman, N., Haglund, P., Bjarke, M., Hallgren, P., 2013. Remaining potential environmental effects of emerging organic contaminants in landfill leachate treatment effluents. Proceedings Sardinia Symposium 2013, Cagliari, Italy, 30/9 -4/10 2013. van Praagh, M., Torneman, N., Johansson, M., Ingelstedt-Frendberg, L., Heander, E., Johansson, A., 2011. Emerging contaminants in leachates- Review and risk assessment. Proceedings Sardinia Symposium 2011, Cagliari, Italy, 3 -8 October 2011.

van Praagh, M., Hartman, C., Brandmyr, E., 2018. Microplastics in landfill leachates in the Nordic Countries. TemaNord 2018:557. Nordic Council of Ministers, ISBN 978-92-893-5915-3 (EPUB), http:// dx.doi.org/10.6027/TN2018-557

Welle F, Franz R., 2018. Microplastic in bottled natural mineral water - literature review and considerations on exposure and risk assessment. Food Additives \& Contaminants Part A: Chemistry, Analysis, Control, Exposure \& Risk Assessment. 2018;35(12):2482-2492. do $\mathrm{i}: 10.1080 / 19440049.2018 .1543957$

Zaman, A.U., Swapan, M.S.H., 2016. Performance evaluation and benchmarking of global waste management systems, Resources, Conservation and Recycling, Volume 114, 2016, Pages 32-41, ISSN 0921-3449, https://doi.org/10.1016/j.resconrec.2016.06.020.

Zhu, L., Birgisson, B., Kringos, N., 2014. Polymer modification of bitumen: Advances and challenges. European Polymer Journal, Volume 54, 2014, Pages 18-38, ISSN 0014-3057, https://doi. org/10.1016/j.eurpolymj.2014.02.005.

Xu, Z., Sui, Q., Aimin Li, Sun, M., Zhang, L., Lyu, S., Zhao, W. 2020. How to detect small microplastics $(20-100 \mu \mathrm{m})$ in freshwater, municipal wastewaters and landfill leachates? A trial from sampling to identification, Science of The Total Environment, Volume 733, 2020, 139218, ISSN 0048-9697, https://doi.org/10.1016/j.scitotenv.2020.139218.

\section{ANNEX 1}

TABLE: Sampling locations for blank sample, stormwater, untreated and, if available, treated leachates and respective sample volumes (in $\mathrm{L}$, blank cells = no leachate treatment)

\begin{tabular}{|c|c|c|c|c|}
\hline Landfill & Untreated leachate & Sample volume & Treated leachate & Sample volume \\
\hline No. & Location & $\mathrm{L}$ & Location & $\mathrm{L}$ \\
\hline 0 & Tap water (PE-bucket) & 105 & & \\
\hline 1 & Pumping station & 120 & & \\
\hline 2 & Pumping station & 80 & & \\
\hline 3 & Pumping station (PE-bucket) & 70 & Pumping station (PE-bucket) & 190 \\
\hline 4 & Pond & 70 & Pipe (PE-bucket) & 210 \\
\hline 5 & Pond & 10 & & \\
\hline 6 & Pumping station & 20 & Pumping station & 5 \\
\hline 7 & Pumping station & 40 & & \\
\hline 8 & Well & 40 & & \\
\hline 9 & Bore hole & 295 & Pipe (PE-bucket) & 255 \\
\hline 10 & Pipe & 307 & & \\
\hline 11 & Pond & 44 & & \\
\hline Storm water & Pond + steel bucket & 36 & & \\
\hline
\end{tabular}

\section{ANNEX 2}

TABLE 2: Microplastic polymers identified by screening and total mass on sample filters after pre-treatment $($ neg $=$ negative, $n . d .=$ non detect, limit <0,001 mg).

\begin{tabular}{|c|c|c|c|}
\hline No. & Polymers detected & Total mass $\mathbf{5 0} \boldsymbol{\mu m}$ filter & Total mass ${ }^{a} \mathbf{5 0 0} \boldsymbol{\mu m}$ filter \\
\hline Unit & & $\mathrm{mg}$ & $\mathrm{mg}$ \\
\hline 0 control & SBR & 8 & 11 \\
\hline 1 & PE, PP, PMB & 64 & 93 \\
\hline 2 & PE, PVC, PS, PET, PA, PU, PMMA & 11 & n.d. \\
\hline
\end{tabular}




\begin{tabular}{|c|c|c|c|}
\hline No. & Polymers detected & Total mass $50 \mu \mathrm{m}$ filter & Total mass ${ }^{a} \mathbf{5 0 0} \mu \mathrm{m}$ filter \\
\hline 3 untreated & PET, PU & 2 & 23 \\
\hline 3 treated & PE, PS, PMB & 5 & 2 \\
\hline 4 untreated & PE, PS, PET, PU & 27 & n.d. \\
\hline 4 treated & PE, PS & 12 & n.d. \\
\hline 5 & SBR, PMB & 60 & 11 \\
\hline 6 untreated & PE, PET, SBR & 9 & 10 \\
\hline 6 treated & SBR & 29 & 122 \\
\hline 7 & PET, PMMA & 23 & 9 \\
\hline 8 & Negative $^{\mathrm{b}}, \mathrm{PE}$ & $483^{b}$ & 15 \\
\hline 9 untreated & PE, PS, PET, PU & 4 & 5 \\
\hline 9 treated & PE, SBR & 21 & 12 \\
\hline 10 & SBR & 11 & 1 \\
\hline 11 & PE, PP, PS, PU, PMB, SBR & 16 & 46 \\
\hline Storm water & $\begin{array}{l}50 \mu \mathrm{m} \text { : PE, PP, PVC, PS, PET, PA, PU, PMMA, PMB, SBR, } 500 \mu \mathrm{m}: \text { PE, PP, PVC, } \\
\text { PS, PET, SBR }\end{array}$ & $<1$ & $<1$ \\
\hline
\end{tabular}

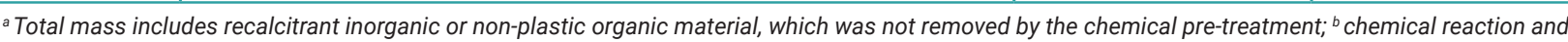
precipitation occurred, see discussion. 